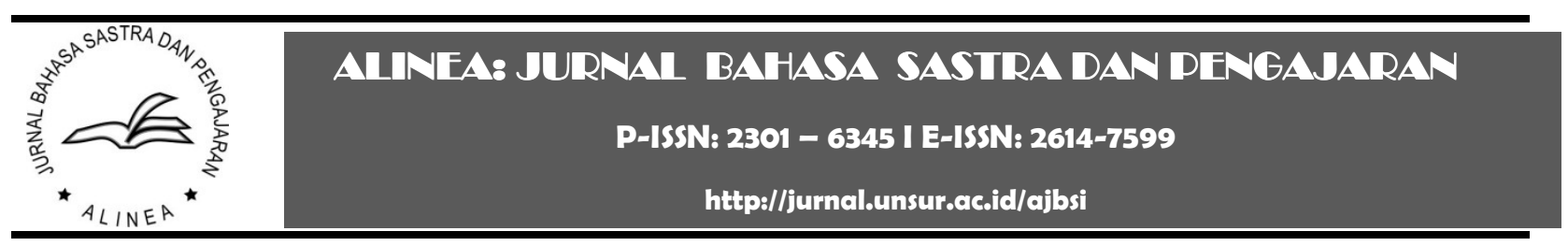

\title{
PENGEMBANGAN E-MODUL MATA KULIAH PEMBELAJARAN BAHASA INDONESIA
}

\author{
Purwati Zisca Diana \& Denik Wirawati \\ Universitas Ahmad Dahlan, Indonesia
}

Riwayat artikel:

Dikirim: 12 Agustus 2021

Direvisi: 9 September 2021

Diterima: 15 September 2021

Diterbitkan: 31 Oktober 2021

\section{Katakunci:}

analisis kebutuhan, e-modul, sumber belajar, bahasa

Indonesia

Keywords:

needs analysis, e-module,

learning resources, Indonesian language

Alamat surat

purwati.diana@pbsi.uad.ac.id

\begin{abstract}
Abstrak:
Artikel ini akan mendeskripsikan hasil analisis kebutuhan terhadap pengembangan rancangan e-modul mata kuliah Pembelajaran Bahasa Indonesia. Analisis kebutuhan ini merupakan bagian dari penelitian dan pengembangan $(R \& D)$. Metode penelitian yang digunakan adalah deskriptif kualitatif. Subjek penelitian adalah mahasiswa semester 4 tahun akademik 2020/2021. Pengumpulan data dilakukan dengan observasi, wawancara, kuesioner, dan analisis dokumen. Analisis data dilakukan dengan teknik analisis interaktif Miles-Huberman, yaitu pereduksian data, penyajian data, dan penarikan kesimpulan. Hasil penelitian, menunjukkan bahwa sumber belajar yang diperlukan mudah dipelajari dan dalam bentuk digital. Sebanyak 77,94\% mahasiswa senang menggunakan e-modul sebagai sumber belajar karena praktis. Dengan demikian, dapat disimpulkan perlu dikembangkan emodul sebagai sumber belajar dalam mata kuliah Pembelajaran Bahasa Indonesia.
\end{abstract}

\begin{abstract}
:
This article will describe the results of the needs analysis on the development of the e-module design for Indonesian Language Learning courses. This needs analysis is part of research and development $(R \& D)$. The research method used is descriptive qualitative. The research subjects are 4th-semester students of the 2020/2021 academic year. Data were collected by observation, interviews, questionnaires, and document analysis. Data analysis was carried out using the Miles-Huberman interactive analysis technique, namely data reduction, data presentation, and conclusion drawing. The results showed that the learning resources needed were easy to learn and in digital form. As many as $77.94 \%$ of students are happy to use e-modules as a learning resource because it is practical. Thus, it can be concluded that it is necessary to develop e-modules as learning resources in Indonesian Language Learning courses.
\end{abstract}

\section{PENDAHULUAN}

Pakar teori pembelajaran kerap menyebut pembelajaran masa Revolusi Industri 4.0 untuk menggambarkan bermacam metode mengintegritaskan teknologi cyber baik secara wujud ataupun nonfisik dalam pendidikan. Pembelajaran masa Revolusi Industri 4.0 merupakan fenomena yang merespons kebutuhan revolusi industri dengan penyesuaian kurikulum baru yang sesuai situasi saat ini.
Kurikulum tersebut sanggup membuka jendela dunia lewat genggaman, contohnya menggunakan internet of things (IoT).

Pembelajaran Era 4.0 di masa pandemi covid-19 jadi salah satu pendorong pelaksanaan pendidikan masa digital (revolusi industri 4.0). Dengan belajar di rumah menggunakan aplikasi, kuliah daring, tutorial, serta seminar daring ialah wujud pelaksanaan revolusi industri 4.0 (Hanum). Dalam keadaan 
di kala ini baik pengajar ataupun peserta didik dipacu untuk menguasai pemakaian teknologi digital. Di sisi lain, peserta didik dituntut pula untuk mengeksplor teknologi serta informasi untuk menyalurkan kreativitasnya lewat inovasi dalam tugas yang diberikan.

Sumber belajar dapat diartikan sebagai informasi yang disajikan dan disimpan dalam berbagai bentuk media untuk membantu siswa belajar sebagai perwujudan kurikulum (Irawati and Fuad Saifuddin). Formatnya tidak dibatasi, baik itu format software atau gabungan dari berbagai format yang digunakan oleh mahasiswa atau dosen (Sitepu).

Sumber belajar dibedakan menjadi empat jenis, yaitu: (1) media dua dimensi (grafik), seperti gambar, foto, grafik, bagan, poster, kartun dan komik; (2) media tiga dimensi, Contoh: model padat, model penampang dan model tumpuk; (3) Media proyeksi, seperti: film, OHP; (4) Lingkungan (Amalia). Bentuk sumber belajar dapat berupa: (1) tempat sekitar atau lingkungan alam; (2) benda, tokoh, buku (instruktur, siswa, media dan sumber pengetahuan lainnya); (3) peristiwa atau peristiwa yang sedang terjadi dan sedang berlangsung, membahas fakta dengan antusias (Smaldino, Sharon E., Deborah L. Lowther).

Modul adalah buku teks, sumber belajar mandiri, berisi topik atau satuan pembelajaran untuk mencapai tujuan pembelajaran tertentu yang telah ditetapkan (Ulya). Buku yang dirancang untuk memungkinkan siswa belajar mandiri tanpa bimbingan pendidik (guru/ dosen) atau di bawah bimbingan guru, jadi modul ini memuat semua komponen dasar dari buku teks tersebut (Wibowo). Menurut Prawidaliga (dalam Ummah, Suarsini, \& Lestari, 2020) modul merupakan bahan ajar yang meliputi tujuan pembelajaran, petunjuk penggunaan, uraian materi, rangkuman, evaluasi, umpan balik, dan tindak lanjut.

Modul elektronik (electronic module) adalah suatu bentuk pajangan yang secara sistematis menyusun materi pembelajaran mandiri ke dalam satuan pembelajaran tertentu dan menyajikannya dalam format elektronik sehingga siswa dapat melakukan kunjungan digital (Herawati and Muhtadi). Modul elektronik merupakan suatu alat atau perangkat pembelajaran yang memuat materi, metode, batasan dan metode evaluasi (Wahyudi). Bahan, metode, batasan dan metode evaluasi tersebut dirancang secara sistematis dan menarik, serta dapat mewujudkan kemampuan yang diharapkan sesuai dengan kompleksitas elektronika (Solihudin JH).

Jika dilihat dari manfaat media elektronik itu sendiri dapat menjadikan proses pembelajaran lebih menarik, interaktif, dapat diselesaikan kapan pun, di mana pun, dan dapat meningkatkan kualitas pembelajaran (Violadini and Mustika). Berdasarkan penafsiran pengertian modul cetak dan e-modul (modul elektronik), tidak ada perbedaan yang mencolok dalam prinsip pengembangan antara modul tradisional (cetak) dan modul elektronik (Arsal et al.). Perbedaannya terletak pada format presentasi fisik. Umumnya modul elektronik disesuaikan dengan komponen yang terdapat pada modul cetak (Afrianti and Qohar).

E-modul yang dikembangkan dalam penelitian ini mencakup materi tentang model dan pendekatan pembelajaran bahasa Indonesia yang berorientasi pada keterampilan berpikir tingkat tinggi (HOTS). Pemilihan topik tersebut disebabkan oleh pendapat mahasiswa yang mayoritas menyatakan bahwa materi tersebut sulit dipahami dan membingungkan untuk membedakan antara model, metode, dan pendekatan pembelajaran. Topik tersebut sesuai dengan materi yang terdapat dalam RPS yang digunakan dalam perkuliahan.

Analisis kebutuhan pengembangan emodul pembelajaran bahasa Indonesia ini meliputi analisis kondisi bahan ajar, analisis kurikulum, serta analisis kebutuhan mahasiswa dan dosen. Analisis kebutuhan secara menyeluruh diharapkan dapat sebagai bahan 
referensi untuk pengembangan rancangan produk berupa e-modul Pembelajaran Bahasa Indonesia yang sesuai dengan kebutuhan mahasiswa dan dosen.

Hal ini diperkuat oleh (Ummah et al.) yang melakukan penelitian tentang analisis kebutuhan pengembangan e-modul berbasis penelitian uji antimikroba pada mata kuliah Mikrobiologi. Hasil penelitian ini menunjukkan bahwa 1) pembelajaran mikrobiologi belum menggunakan pembelajaran berbasis proyek sesuai dengan KKNI; 2) mahasiswa merasa kesulitan untuk menggunakan bahan ajar selain dari buku teks; dan 3) mahasiswa mengalami kesulitan pada materi mikrobiologi kesehatan terutama uji antimikroba. Berdasarkan hasil penelitian tersebut dapat disimpulkan bahwa perlu dikembangkan bahan ajar berupa e-modul berbasis penelitian uji antimikroba pada mata kuliah Mikrobiologi.

Penelitian lain terkait analisis kebutuhan pengembangan modul pembelajaran juga dikemukakan oleh (Deviana). Analisis kebutuhan pengembangan modul pembelajaran berbasis kearifan lokal Kabupaten Tulungagung ini meliputi analisis kurikulum, analisis siswa, serta analisis kondisi lapangan. Analisis kebutuhan yang dilakukan secara menyeluruh dan akurat diharapkan dapat dikembangkan modul pembelajaran berbasis kearifan lokal Kabupaten Tulungagung yang sesuai dengan kebutuhan lapangan.

\section{METODE}

Metode penelitian ini merupakan bagian dari penelitian pengembangan (Research and Development). Metode penelitian dan pengembangan menurut Borg and Gall yang telah dimodifikasi oleh Sugiyono. Ada sepuluh langkah penelitian dan pengembangan, yaitu: 1) Penelitian dan pengumpulan data, yang meliputi pengukuran kebutuhan, studi literatur, dan penelitian dalam skala kecil. 2) Perencanaan pengembangan produk. 3)
Pengembangan produk awal. 4) Uji coba produk awal. 5) Penyempurnaan produk awal. 6) Uji coba produk yang telah disempurnakan. 7) Penyempurnaan produk yang telah disempurnakan. 8) Pengujian produk yang telah disempurnakan. 9) Uji lapangan produk yang telah disempurnakan. 10) Implementasi dan institusionalisasi produk (Sugiyono).

Dari sepuluh langkah penelitian dan pengembangan di atas, pada penelitian baru pada tahap pendahuluan, yaitu penelitian dan pengumpulan data yang meliputi pengukuran kebutuhan, studi literatur, dan observasi. Hal ini bertujuan untuk menentukan produk yang harus dihasilkan sesuai dengan analisis kebutuhan.

Jenis penelitian yang digunakan dalam tahap pendahuluan ini adalah deskriptif kualitatif. Penelitian ini dilakukan di Program Studi Pendidikan Bahasa dan Sastra Indonesia, Fakultas Keguruan dan Ilmu Pendidikan, Universitas Ahmad Dahlan Yogyakarta. Subjek uji coba penelitian ini adalah mahasiswa semester 4 yang sedang menempuh mata kuliah Pembelajaran Bahasa Indonesia. Pengumpulan data dilakukan dengan observasi pembelajaran, wawancara, angket, dan analisis dokumen. Teknik analisis data dilakukan dengan teknik analisis interaktif

\section{HASIL PENELITIAN}

Analisis kebutuhan penyusunan e-modul Pembelajaran Bahasa Indonesia ini, meliputi analisis kondisi bahan ajar, analisis kurikulum, serta analisis kebutuhan mahasiswa dan dosen pengampu mata kuliah. Analisis kondisi bahan ajar dilakukan dengan observasi saat proses pembelajaran dan bahan ajar yang digunakan pada mata kuliah Pembelajaran Bahasa Indonesia. Analisis kurikulum dilakukan dengan menganalisis dokumen perangkat pembelajaran. Analisis kebutuhan terhadap mahasiswa dan dosen diperoleh melalui wawancara dan kuesioner. 


\section{Kondisi Bahan Ajar}

Berdasarkan hasil observasi selama proses pembelajaran, tampak bahwa mahasiswa antusias dalam mengikuti perkuliahan Pembelajaran Bahasa Indonesia yang dilakukan secara daring baik dengan sistem sinkronus maupun asinkronus. Hal tersebut tampak dari jumlah kehadiran, rata-rata kehadiran $92,86 \%$. Namun, antusias kehadiran tersebut tidak didukung dengan keaktifan mahasiswa selama proses perkuliahan. Mahasiswa cenderung berikap pasif dan dosen menjadi pusat pembelajaran.

Ketidakaktifan mahasiswa dalam proses pembelajaran disebabkan oleh bahan ajar yang digunakan dosen hanya menggunakan power point (PPT) dan kurangnya stimulus yang diberikan oleh dosen untuk menarik respons mahasiswa. Dosen tidak menggunakan bahan ajar lain selain PPT. Buku referensi yang digunakan pun hanya terbatas, yaitu Pembelajaran Bahasa Indonesia Era Industri 4.0 karya Prof. Dr. Sarwiji Suwandi, M.Pd. sebagai buku referensi wajib.

Penelitian senada juga dilakukan oleh (Deviana), adapun hasil analisis kurikulum menunjukkan bahwa jaringan tema, serta analisis buku guru dan buku siswa terdapat beberapa kompetensi dasar yang tidak sesuai dengan subtema serta penggunaan indikator yang diulang-ulang. Selain itu, contoh yang diberikan di buku siswa maupun buku guru tidak sesuai dengan lingkungan sekitar siswa.

\section{Dokumen Perangkat Pembelajaran}

Silabus merupakan salah satu acuan dalam penyusunan bahan ajar. Manfaat silabus diharapkan dapat menentukan bahan ajar yang sesuai kebutuhan dalam mencapai standar kompetensi dan kompetensi dasar pada mahasiswa. Penelitian ini juga mengkaji Rencana Pembelajaran Semester (RPS) yang digunakan selama ini. Hasil analisis dokumen pada RPS masih menunjukkan beberapa kekurangan, antara lain: 1) Rumusan capaian kompetensi dalam RPS belum sampai pada kemampuan berpikir tinggi (HOTS). 2) Rancangan pengalaman belajar masih terpusat pada pembelajaran teoretis di kelas. 3) Sumber belajar yang digunakan pun masih terbatas; dan 4) beberapa materi yang dibahas tumpang tindih dengan mata kuliah pembelajaran lain.

Dalam penelitian inovasi sumber belajar menjadi prioritas. Inovasi yang ditawarkan berupa pengembangan e-modul yang dapat digunakan secara interaktif sehingga memudahkan mahasiswa dan dosen dalam proses pembelajaran pada situasi pandemi saat ini. Adapun materi yang dikembangkan tentang model dan pendekatan pembelajaran bahasa Indonesia yang berorientasi pada keterampilan berpikir tingkat tinggi (HOTS). Alasan pemilihan materi tersebut karena dianggap materi yang paling sulit dan membingungkan bagi mahasiswa. Selain itu, juga terdapat revisi pada RPS yang sesuai dengan kebutuhan pembelajaran saat ini. Adapun materi yang direvisi pada RPS, antara lain: materi terkait model pembelajaran, pendekatan pembelajaran, implementasi pembelajaran bahasa Indonesia berbasis HOTS, dan menambahkan konsep merdeka belajar.

\section{Kebutuhan Mahasiswa}

Hasil kuesioner analisis kebutuhan mahasiswa yang berisi tentang sumber belajar yang disukai, diperoleh hasil sebagai berikut. Sebanyak $100 \%$ mahasiswa menyatakan bahwa variasi dalam sumber belajar itu penting. Selain itu, sebanyak 78,21\% mahasiswa berpendapat bahwa buku teks lebih mudah dipelajari. Sebanyak 73,87\% mahasiswa berpendapat terkait penggunaan $e$-book lebih mudah dipelajari, sedangkan sebanyak $77,94 \%$ mahasiswa berpendapat bahwa penggunaan e-modul lebih mudah dipelajari. Adapun hasil analisis kebutuhan terhadap mahasiswa tampak pada rincian tabel 1 di bawah ini. 
Tabel 1 Analisis Kebutuhan E-Modul untuk Mahasiswa

\begin{tabular}{clcc}
\hline No. & \multicolumn{1}{c}{ Hal } & Ya & Tidak \\
\hline $\mathbf{1}$ & $\begin{array}{l}\text { Pendapat mahasiswa } \\
\text { terkait pentingnya } \\
\text { sumber belajar }\end{array}$ & $100 \%$ & - \\
\hline $\mathbf{2}$ & $\begin{array}{l}\text { Pendapat mahasiswa } \\
\text { bahwa buku teks lebih } \\
\text { mudah dipelajari }\end{array}$ & $78,21 \%$ & $21,79 \%$ \\
\hline $\mathbf{3}$ & $\begin{array}{l}\text { Pendapat mahasiswa } \\
\text { bahwa } \text { e-book lebih } \\
\text { mudah dipelajari }\end{array}$ & $73,87 \%$ & $26,13 \%$ \\
\hline $\mathbf{4}$ & $\begin{array}{l}\text { Pendapat mahasiswa } \\
\text { bahwa } e \text {-modul lebih } \\
\text { mudah dipelajari }\end{array}$ & $77,94 \%$ & $22,06 \%$ \\
\hline $\mathbf{5}$ & $\begin{array}{l}\text { Pendapat mahasiswa } \\
\text { bahwa ppt lebih mudah } \\
\text { dipelajari }\end{array}$ & $56,39 \%$ & $43,61 \%$ \\
\hline
\end{tabular}

Hasil analisis terhadap kebutuhan mahasiswa dalam Pembelajaran Bahasa Indonesia antara lain, mahasiswa cenderung aktif dalam mengikuti perkuliahan, terutama dalam mencari literatur sebagai sumber belajar mandiri. Meskipun terdapat beberapa mahasiswa yang masih kurang termotivasi sehingga kurang aktif pula dalam mengikuti perkuliahan. Penyebab rendahnya motivasi pada mahasiswa di antaranya karena penggunaan model pembelajaran yang tidak sesuai dengan karakteristik mahasiswa, media yang digunakan kurang menarik, dan sumber belajar yang kurang mendukung (Sani).

Oleh karena itu, guna meningkatkan motivasi mahasiswa dalam belajar, salah satu upaya yang dilakukan adalah dengan mengembangkan e-modul sebagai pendukung sumber belajar yang mudah dipelajari. Dampak pandemi covid-19 ini juga dirasakan pada sektor pendidikan, yang mengakibatkan mahasiswa pun kurang termotivasi untuk belajar secara mandiri.

Pada aspek sumber belajar, sebagian besar mahasiswa tidak memiliki buku referensi. Hal tersebut disebabkan oleh minimnya sumber belajar terkait dengan mata kuliah Pembelajaran Bahasa Indonesia. Dosen pengampu mata kuliah tersebut juga belum memproduksi buku ajar sebagai penunjang. Oleh karena itu, mahasiswa selama ini hanya mengandalkan materi power point (PPT) dari dosen. Ditambah lagi dengan kondisi negara ini yang dilanda pandemi covid-19. Hal tersebut memperburuk proses belajar mengajar yang tidak maksimal. Terkadang dosen yang hanya sekadar mengirimkan materi dalam bentuk power poin tanpa memberikan penjelasan. Hal itu membuat mahasiswa semakin kurang termotivasi.

Hasil penelitian pada analisis kebutuhan siswa yang dilakukan oleh (Deviana) dapat disimpulkan bahwa siswa kurang mengenal lingkungan sekitar dan kurang mengetahui kearifan lokal yang ada di daerahnya sendiri. Alasan itulah yang mendorong pengembangan modul pembelajaran kearifan lokal ini dilakukan.

\section{Kebutuhan Dosen}

Analisis kebutuhan e-modul untuk dosen pengampu mata kuliah Pembelajaran Bahasa Indonesia berisi tentang aktivitas mahasiswa, model pembelajaran yang diterapkan, media pembelajaran yang digunakan, materi yang dianggap sulit, dan hasil belajar mahasiswa, serta identifikasi sumber belajar yang dibutuhkan. Adapun hasil analisis kebutuhan terhadap dosen, antara lain sebagai berikut.

1. Mahasiswa antusias dan aktif dalam mengikuti perkuliahan dan mencari sumber literatur mengenai topik yang dipelajari dalam mata kuliah Pembelajaran Bahasa Indonesia, meskipun masih terdapat beberapa mahasiswa yang kurang aktif.

2. Model pembelajaran yang biasa dilakukan selama ini menggunakan metode ceramah, diskusi, dan Problem Based Learning (PBL).

3. Media pembelajaran yang digunakan berupa PPT.

4. Materi yang dianggap sulit bagi mahasiswa antara lain: model pembelajaran, pendekatan pembelajaran dalam Kurikulum 2013, dan implementasi pembelajaran bahasa Indonesia berbasis HOTS. Hasil belajar mahasiswa pada materi tersebut antara $57 \%-78 \%$. 
5. Sumber belajar yang perlu dikembangkan untuk memudahkan mahasiswa dalam belajar adalah e-modul yang didalamnya berisi fokus materi berupa teori dan contoh aplikasinya.

Berdasarkan hasil analisis kebutuhan di atas, model pembelajaran yang digunakan oleh dosen, yaitu Problem Based Learning (PBL) telah sesuai dengan anjuran pemerintah dalam Sisdiknas tahun 2014. Senada dengan (Apriani) yang menyatakan tentang model pembelajaran PBL, yaitu pembelajaran yang dapat merangsang siswa untuk belajar. Model pembelajaran berbasis masalah ini melibatkan siswa dalam proses pembelajaran yang aktif dan kolaboratif. Sementara, metode diskusi dan ceramah yang dilakukan juga disertai dengan media pembelajaran yang menarik, sehingga mahasiswa pun dapat memberikan kontribusi dalam pembelajaran.

Media pembelajaran yang selama digunakan adalah power point (PPT). Akan tetapi, PPT yang digunakan lebih banyak berisi teks saja, belum ditemukan PPT yang interaktif atau terdapat gambar dan video. Selain media pembelajaran, diperlukan juga bahan ajar sebagai sumber belajar.

Materi Pembelajaran Bahasa Indonesia yang dianggap sulit oleh mahasiswa antara lain: model pembelajaran, pendekatan pembelajaran dalam Kurikulum 2013, dan implementasi pembelajaran bahasa Indonesia berbasis HOTS. Hal itu terlihat dari hasil belajar mahasiswa pada materi tersebut antara 57\%-78\%. Oleh karena itu, untuk memberikan solusi pada permasalahan tersebut dirancang e-modul yang meliputi materi tentang model dan pendekatan pembelajaran bahasa Indonesia yang berorientasi pada keterampilan berpikir tingkat tinggi (HOTS).

Pengembangan e-modul ini merupakan pilihan yang dapat dimanfaatkan dalam proses pembelajaran. Hal ini diharapkan dapat membantu mahasiswa belajar secara mandiri. Dalam e-modul terdapat petunjuk cara penggunaan, uraian materi, latihan soal sebagai bentuk evaluasi, dan umpan balik sebagai bentuk interaksi antara dosen dengan mahasiswa. E- modul ini digunakan dalam pertemuan terbatas untuk memudahkan proses pembelajaran. E-modul ini juga dirancang menggunakan flip $p d f$ corporate, yang dirancang dalam bentuk e-modul interaktif sehingga mampu memudahkan mahasiswa dalam belajar dan menghilangkan asumsi sulit terhadap materi model dan pendekatan pembelajaran bahasa Indonesia yang berorientasi pada keterampilan berpikir tingkat tinggi (HOTS).

Perihal di atas, senada dengan hasil penelitian terdahulu yang telah dilakukan oleh (Purwoko et al.) tentang kondisi analisis kebutuhan e-modul yang menunjukkan hasil bahwa peserta didik memerlukan bahan ajar yang menarik dan menyenangkan pada pembelajaran matematika, seperti modul berbasis elektronik. Hal ini juga didukung dengan hasil penelitian (Utami and Yuwaningsih) yang menunjukkan bahwa kebutuhan e-modul dapat menjadi alternatif dalam pembelajaran meskipun pada materi yang sulit. Berdasarkan hal tersebut, analisis kebutuhan pengembangan e-modul sebagai sumber belajar pada mata kuliah Pembelajaran Bahasa Indonesia dapat dirancang sebagai pendukung bahan ajar alternatif yang bersifat memudahkan belajar mahasiswa, serta dapat menjadi media interaktif yang menarik di tengah pembelajaran daring akibat pandemi Covid-19.

\section{SIMPULAN}

Berdasarkan hasil penelitian terhadap analisis kebutuhan pengembangan e-modul Pembelajaran Bahasa Indonesia dapat disimpulkan bahwa sumber belajar sangat diperlukan untuk mahasiswa guna memfasilitasi belajar baik secara mandiri maupun bersama dosen. Sebanyak $77,94 \%$ mahasiswa senang menggunakan e-modul sebagai sumber belajar karena dianggap lebih mudah dipelajari. Emodul lebih sederhana, tetapi lengkap akan isinya, yang meliputi tujuan pembelajaran, petunjuk penggunaan, uraian materi, 
rangkuman, dan evaluasi. Pengembangan emodul dalam penelitian ini dirancang untuk memberikan solusi bagi mahasiswa yang mengalami kesulitan dalam beberapa materi terkait model dan pendekatan pembelajaran, sehingga dalam penelitian ini dirancang emodul tentang model dan pendekatan pembelajaran bahasa Indonesia yang berorientasi pada keterampilan berpikir tingkat tinggi (HOTS).

\section{UCAPAN TERIMA KASIH}

Ucapan terima kasih disampaikan untuk Lembaga Penelitian dan Pengabdian kepada Masyarakat (LPPM) Universitas Ahmad Dahlan Yogyakarta yang telah memberikan dukungan baik berupa pendanaan terhadap penelitian ini dan motivasi, sehingga publikasi ini berjalan lancar. Terima kasih pula disampaikan untuk para pimpinan, Rektor UAD, Dekan FKIP UAD, dan Kaprodi PBSI FKIP UAD, yang telah memberikan dukungan dan motivasi untuk kelancaran penelitian ini.

\section{DAFTAR PUSTAKA}

Afrianti, Reny Eka Nur, and Abd. Qohar. "Pengembangan E-Modul Berbasis Kontekstual pada Materi Program Linear Kelas XI.” Jurnal Edukasi Matematika dan Sains, vol. 7, no. 1, 2019, p. 22, doi:10.25273/jems.v7i1.5288.

Amalia, Suci Nur. Pengembangan Bahan Ajar Menulis Berita Peristiwa Multikultural dengan Pendekatan Kontekstual Untuk Siswa Smp Kelas Viii. 2013.

Apriani, Neni Mariam. "Meningkatkan Kreativitas Menulis Teks Anekdot dengan Menggunakan Model Problem Based Learning." Alinea: Jurnal Bahasa, Sastra, dan Pengajaran, vol. 8, no. 2, 2019, p. 99, doi:10.35194/alinea.v8i2.440.

Arsal, Muhammad, et al. "Pengembangan Media Pembelajaran E-Modul Materi Sistem Peredaran Darah Pada Kelas XI MIPA SMAN 6 BARRU.” Prosiding Seminar Nasional Biologi VI, 2019, pp. 434-42, https://ojs.unm.ac.id/semnasbio/article/view/10594/6211.

Deviana, Tyas. “Analisis Kebutuhan Pengembangan Modul Pembelajaran Berbasis Kearifan Lokal Kabupaten Tulungagung Untuk Kelas V Sd Tema Bangga Sebagai Bangsa Indonesia." Jurnal Pemikiran dan Pengembangan Sekolah Dasar (JP2SD), vol. 6, no. 1, 2018, p. 47, doi:10.22219/jp2sd.v6i1.5902.

Hanum, Numiek Sulistyo. "Keefektifan E-Learning Sebagai Media Pembelajaran (Studi Evaluasi Model Pembelajaran E-Learning SMK Telkom Shandy Putra Purwokerto)." Jurnal Pendidikan Vokasi, vol. 3, no. 1, 2013, p. 94.

Herawati, Nita Sunarya, and Ali Muhtadi. "Pengembangan Modul Elektronik (e-Modul) Interaktif Pada Mata Pelajaran Kimia Kelas XI SMA.” Jurnal Inovasi Teknologi Pendidikan, vol. 5, no. 2, 2018, pp. 180-91, doi:10.21831/jitp.v5i2.15424.

Irawati, Hani, and Much. FuadSaifuddin. "Analisis Kebutuhan Pengembangan Bahan Ajar Mata Kuliah Pengantar Profesi Guru Biologi di Pendidikan Biologi Universitas Ahmad Dahlan Yogyakarta Analysis of Needs Development Material Learning Program Introductory 
Profession of Biological Teacher in Biolog.” Jurnal Pembelajaran Biologi, vol. 7, no. 2, 2018, pp. 96-99, file:///C:/Users/ASUS/Downloads/27636-65258-1-SM.pdf.

Purwoko, Riawan Yudi, et al. "Analisis Kebutuhan Pengembangan E -Modul Berbasis Etnomatematika Produk Budaya Jawa Tengah.” Jurnal Penelitian Matematika Dan Pendidikan Matematika, vol. 5, no. 1, 2020, pp. 1-8.

Sani, Ridwan Abdullah. Strategi Belajar Mengajar. Cetakan pe, PT Raja Grafindo Persada, 2019.

Sitepu, B. P. "Buku Teks Pelajaran Berbasis Aneka Sumber." Pendidikan Penabur, vol. 10, no. $7,2008$.

Smaldino, Sharon E., Deborah L. Lowther, and James D. Russell. Instructional Technology \& Media for Learning. Teknologi Pembelajaran dan Media Untuk Belajar. 9th ed., Kencana Prenada Media Group, 2012.

Solihudin JH, Taufik. "Pengembangan E-Modul Berbasis Web untuk Meningkatkan Pencapaian Kompetensi Pengetahuan Fisika pada Materi Listrik Statis dan Dinamis SMA.” WaPFi (Wahana Pendidikan Fisika), vol. 3, no. 2, 2018, p. 51, doi:10.17509/wapfi.v3i2.13731.

Sugiyono. Metode Penelitian dan Pengembangan (Research and Development). Cetakan ke, Alfabeta, 2019.

Ulya, Fadhliyatul. Pengembangan Modul Biologi Berintegrasi Nilai-Nilai Islam dengan Pendekatan Inkuiri pada Sub Materi Pencemaran Lingkungan Kelas X di MAN Kendal. 2018.

Ummah, R., et al. "Pengembangan E-Modul Berbasis Penelitian Uji Antimikroba pada Matakuliah Mikrobiologi." Jurnal Pendidikan: Teori, Penelitian, dan Pengembangan, vol. 5, no. 1, 2020, p. 572-579.

Utami, Wahyu Tri, and Dian Ariesta Yuwaningsih. "Analisis Kebutuhan Pengembangan EModul Pada Pokok Bahasan Turunan Menggunakan Kvisoft Flipbook Maker Pro Untuk Siswa SMA Kelas XI.” Prosiding Seminar Nasional Konferensi Ilmiah Pendidikan, vol. 1, no. 1,2020 , pp. $158-60$.

Violadini, Ririn, and Dea Mustika. "Jurnal Basicedu." Jurnal Basicedu, vol. 1, no. 1, 2019, pp. $1-9$.

Wahyudi, Dudi. "Pengembangan E-Modul dalam Pembelajaran Matematika SMA Berbasis Android." GAUSS: Jurnal Pendidikan Matematika, vol. 2, no. 2, 2019, p. 1, doi:10.30656/gauss.v2i2.1739.

Wibowo, Edi. "Pengembangan Bahan Ajar E-Modul dengan Menggunakan Aplikasi Kvisoft Flipbook Maker.” Skripsi, 2018, http://repository.radenintan.ac.id/3420/1/SKRIPSI FIX EDI.pdf. 